\title{
The Necessity of Ecological Education in Wuling Mountain Area
}

\author{
Hongzhen $\mathrm{Su}$ \\ Three Gorges University School of Literature and \\ Media \\ YiChang, China \\ suhongzhen@foxmail.com
}

\author{
Yan Wang \\ Three Gorges University School of Public \\ Administration and Law \\ YiChang, China \\ 1147338537@qq.com
}

\begin{abstract}
Wuling Mountain Area is one of the areas where economic development is slow, but it also reaches ecological resources. Hence, joining the environmental protection and the economic development is of great significance in the area. This paper analyzes the necessity of implementation of ecological education in Wuling Mountain Area, the statue of the ecology and education in Wuling Mountain Area, at last, it conceives Wuling Mountain Area of ecological education system from the following five aspects, such as, creating an atmosphere, clear objectives, developing curriculum and training teachers.
\end{abstract}

Keywords-ecological education; Wuling Mountain Area; necessity; system construction

\section{INTRODUCTION}

Ecological education is the education for the protection of nature and the protection of the environment, in June if 1992, the United Nations Environment and Development Conference in the "Agenda 21" stressed that "education for sustainable development is critical, it can improve people deal with environment and development issues ability ", the ecological education reached to a very high degree. Due to geographical constraints, the technological level and natural conditions of Wuling Mountain Area makes it be in a slow speed and low quality of economic development which has lagged far behind the other in the eastern areas of the city. The ecological function has a pivotal position both in the country and the world. Carrying out ecological education area is important for overall economic development and environmental protection.

\section{NECESSITY}

Wuling Mountain Area belongs to one of the nine regional ecological good, rich ecological resources, forest resources is extremely rich in biodiversity is good, as the "Central Animal and Plant gene pool" area of ecological value as follows:

\begin{tabular}{|l|l|}
\hline Forest area & 6.12 million hectares \\
\hline Forest coverage & $60.1 \%$ \\
\hline $\begin{array}{l}\text { Value of forest ecosystem } \\
\text { services }\end{array}$ & $\$ 602$ million \\
\hline Drainage area & 4.86 million hectares \\
\hline $\begin{array}{l}\text { The value of ecosystem } \\
\text { services watershed }\end{array}$ & $\$ 41.3$ billion \\
\hline
\end{tabular}

Figure 1. area of ecological value

Wuling Mountain Area is the core areas of subtropical forest system of Yangtze River, which is the important water conservation areas and ecological barrier and is the world's eight centers of origin of crops, the core area of Chinese subtropical forest ecosystems and biodiversity conservation in 17 key areas. Full implementation of the construction of ecological civilization, attaches great importance to ecological education is Wuling Mountain Area to achieve leapfrog development, sustainable development, scientific development of practical needs and strategic needs, manifested in the following aspects:

\section{A. Ecological education is the fundamental way to build an ecological civilization.}

Ecological education is based on ecology, dissemination of ecological knowledge and ecological culture, improving people's ecological awareness and ecological literacy and creating ecological civilization education. Raising the level of ecological awareness of the public is inseparable from social groups to carry out the implementation of effective ecological education, ecological education is carried out, the effect is a direct response to the ecological education level of social consciousness. Building environment-friendly ecological civilization is inseparable raise ecological awareness of the masses, while the level of ecological awareness increases, depending on the ecological education, so that ecological education is the fundamental way to build ecological civilization. In addition, building an ecological civilization is inseparable from scientific theory to support science and technology, support scientific method, scientific system, and scientific theories, methods, techniques; system design relies on education. Development of ecological education 
for the protection of the ecological environment to provide effective theory, techniques and methods, to provide intellectual protection and fundamental support for the construction of ecological civilization.

\section{B. The level of ecological education can measure the level of civilization of a country}

The purpose of education is to promote ecological harmony between human and nature, resolve conflicts between human and the natural environment, regulate human behavior, to establish good ethics, moral and aesthetic taste in the middle of the community people, , church people recognizing the importance of the environment, and how to correct the society live in harmony with nature, make people know the coexistence between itself and the environment, the relationship between co-development, and how to effectively live with nature, to achieve their own purposes at the same time without ignoring the environment. There is a problem in the natural environment, human beings can effectively solve the problem and save the natural environment caused damage and injury. Concerned about environmental problems, humanity has become the consensus of the world. Environmental problems of the world become increasingly serious, which causes great concern to all countries, especially developing countries. There is a big flaw in the handling of the natural environment and other issues, mostly at the expense of the natural environment but also to seek food and clothing and survival of the state, the developed countries have already had the lessons of damaging environment and material resources to solve the series of environmental problems. In a country, a degree of harmony with the natural environment along the region reflects the contradiction between man and nature and level of ability that country or region. Similarly, the ability and level of education as the level of ecological harmony between man and nature also can reflect and measure the level of social civilization of a country.

\section{The ecological education is the best means of "prevention is better than disaster relief," the}

According to the data of "2014 China Environmental Bulletin", in the new standards of conduct air quality monitoring of 161 cities of 2014, the compliance rate of the annual average air quality standards of only 16 cities was less than $10 \%$, while opposed to air quality standards of the city which was up to 145 , accounting for $90.1 \%$. Chinese urban air quality has been very serious harm to the vital interests of the public, in addition, there are a lot of ecological crisis is a latent or covert way threaten the survival of humanity. The haze event of this year in this environmental governance to the wave of public opinion, the more aroused concern and attention, along with indepth study of the human environment, there have been more and more people who are aware of environmental problems and the key is not to deal with environmental issues and has caused harm, but to defense continues to destroy the source of the natural environment on which people depend for survival, "prevent" the meaning and effect is much greater than "relief." But the environmental problem is a systemic problem, not a unilateral which is able to handle well, in order to solve environmental problems, radical environmental pollution and destruction, which is bound to reach a social consensus and build ecooriented society, so that the whole community involved is and achieved.. The only feasibility and countermeasure for this purpose and effect is to the whole society for environmental education, ecological education, so that ecological education is "prevention is better than disaster relief," which is the most effective and sustainable manner and means.

\section{STATUS}

Wuling Mountain Area in full use of the existing climatic conditions and a variety of ecological resources, based on the ecological education is also a useful exploration. Such as Chongqing Municipal Education Commission early in 2011 promulgated the "really good primary and secondary school environmental education work," (Yu teach group [2011] No. 80), in accordance with the relevant counties have the spirit of local conditions to carry out effective Ecological Practice Education. For example, combining Youyang county situation, actions are targeted to carry out ecological education. For third grade students of primary school, the school launched a close, appreciate and love nature, the perception of the surrounding environment education and daily life and the environment linked to master the basic norms of environmental protection; for Grade 4 - Grade 6 students, the school was conducted to explore the home environment, contact the environmental changes and feelings of people's lives, and to develop environmentally friendly habits; for junior high school students, the school guided students to understand the regional and global environmental problems and their bloody lessons, thinking of environment between human and social development, culture and consciously take environmentally friendly actions; for high school students, the school made in-depth understanding of the complexity of the environmental issues, understand the need to solve the environmental problems of the community in economy, technology, policies and regulations, ethics and other joint efforts, to develop students concern about environmental awareness and responsibility.

But the overall status quo of Wuling Mountain Area is not optimistic ecological education, the majority of areas are yet to realize the importance of ecological education, yet to take any effective means and measures, area development of ecological education is imminent.

\section{SYSTEM CONSTRUCTION}

\section{A. To create an atmosphere, to reach consensus on ecological education}

Wuling Mountain Area which is to ensure environmental protection and to build long-term protection mechanism is currently an important development strategy Wuling Mountain Area in the future for a long period of time, it is taken as a center-depth publicity. Its workers to establish a sense of responsibility, sense of mission and pride, consciously and actively join them, dig deep and comprehensive system of local resources and experience to 
enhance the cultural connotation of propaganda, and actively offer advice and suggestions to better serve Wuling Mountain Area environmental protection, to create an ecological civilization, and to create a good social atmosphere, so that more people consciously participate in ecological and environmental protection in the past. Mainstream media steps up publicity efforts to make the press, radio, television and the Internet together to create synergy, setting off the hype environmental protection. To promote the party and central determination and implementation of ecological and environmental protection measures, in-depth country, to promote its new dynamic ecological and environmental protection. In addition, the regional have planned, to promote eco-education strategy to carry out the work, creating a "celebrity card", "race card." The most effective way to promote the area is to carry out ecological education.

\section{B. Increase research, a clear ecological education goals}

The current existing content and form of Wuling Mountain Area is a lack of ecological education, the majority of primary and secondary school science rational. The efforts of the whole ecological education which teachers made according to their own understanding have no clear educational goals, resulting in primary and secondary education enhancements cannot effectively play. In addition, the lack of a clear educational goals results in ecological education inconsistencies between low-grade and high-grade and different schools, leading that early education and post-educational are not able to contact them, making it impossible to reach a common effect of ecological education. Therefore, the theoretical study of ecological education should be increased, and the common program and goals of ecological education and the standardization, clarification should be explored for different grades, students ages corresponding milestones while maintaining among the target continuity, so as to effectively ensure the quality and effectiveness of education. Different schools take local conditions in accordance with unity of purpose and effective ecological education measures can really be taken as ecological education, to achieve the purpose of long-term protection of ecological environment..

\section{A solid foundation, develop ecological education curriculum}

Throughout the course of the current ecological education of Wuling Mountain Area in terms of primary and secondary schools, mostly is related to environmental protection is based on Arbor Day holiday, Earth Day as the theme, carrying out the associated environmental practices and educational activities, teaching content presentation fragmentation diversification, daily life and other features, there is no clear course should have systematic, logical and inheritance. Therefore, relying on ecological education philosophy as a guide, follow the law of education, organize relevant experts and scholars, teachers and grassroots educators, according to the characteristics of students of different ages, develop curricula, scientific and standardized curriculum design and compile the popular eco educational materials. Curriculum system and textbook content needs special attention openness to explore and practice, allow students to explore knowledge in practice, with teachers' correct guidance, to ensure the effectiveness and the effectiveness of education. In addition to the curriculum system, system, should be carried out around the relevant holiday themed activities, class meetings, combined with the characteristics of the actual school, to carry out some ground gas, in-depth educational activities. Finally, ecological education programs also need to conclude an effective evaluation and monitoring system, the evaluation of students is not limited to academic performance and test scores, personal qualities and skills in ecological environmental protection of students should be taken more consideration of .

\section{Attaches great importance to cultivating an eco- education teacher}

Education is the foundation, educational and teachercentered plans; teachers are the first resource education. Implementation and development of ecological education, the same cannot be done without a professional team of teachers. For education has not yet entered the ranks of college students, the normal students in the training process and content aspects of ecological education, improve the overall quality of potential teachers; for primary and secondary school teachers have been employed, and established a sound system of learning and training of teachers, the implementation of teacher training credit system, take Dinggang replacement training, schoolbased training, distance training, etc., to strengthen primary and secondary school teachers, especially rural teachers special training. In addition, to select, reward and promote ecological education in practice, there is a sticker particularly outstanding achievements and contributions of teachers, to set an example, sum up experience, to play in the field of expertise of the exemplary role and contribution of teachers, train and gather a group of discipline talent and innovative team teaching a greater impact for the work of ecological education of adequate reserves, rich teaching resources.

\section{E. Integration of resources, and comprehensively promote ecological education}

The key to promote eco-educational practice is to let each share of social forces be involved, their ecological education is not only the participants, but also the beneficiaries and recipients of the ecological education, and therefore the more extensive scope of participation is, the more significant effectiveness of the education effect will be. Ecological education does not only lie in cultivating an eco-consciousness of society, improving the ecological consciousness, more importantly, it lies in mobilizing people to join the ecological protection movement. If every citizen can be mobilized to get 
involved to change the increasingly serious ecological crisis situations and the integration of social resources just around the corner,and actively participate in the educational process, the ecological significance will be important.

Currently, the society has a lot of civil society organizations and voluntary agencies, and actively participates environmental protection and other fields, the Wuling Mountain Area can take advantage of this stock of social forces, promote the development time ecological education area and the integration of civil society into government planning resources and school teaching.

\section{ACKNOWLEDGMENT}

Funding for this research was provided through the National Social Science Fund (No.13BMZ057). The authors would like express their gratitude for the support.

\section{REFERENCES}

[1] Zheng Guoshen, Li Lianyi..(2012).On the Current Situation and Enhancement of Ecological Civilization Quality of Vocational College Students,Edecation and Teaching Research.6,86-92

[2] ChenYing.(2013).Path to poverty alleviation and development in Wuling Mountain Area selection, Hunan Administration Institute.1 ,77-81

[3] ZhuGuofen.(2006).Construction with Chinese characteristics, ecolo gical education system, Environmental Education,6,26-29

[4] 2014 China State of the Environment, http://www.chinadaily.com. cn/hqcj/xfly/2015-06-05/content_13804122.html (2015-0605)[2015-06-07]

[5] Alma Dea Morani. Art in medical education: Especially plastic surgery[J]. Aesthetic Plastic Surgery, 1992, 16(3).

[6] Chad Abraham Minnich. What is education? Polish and American definitions of education as observed in the theory and practice of high school/secondary school literature and history lessons[D]. University of Southern California, 1999.

[7] Friedman Jeremy N. The case for writing case reports.[J]. Pediatrics and Child Health, 2008, 11(6).

[8] Miller K A. "So cruel": political and domestic duty in writing of the First World War.[J]. Clio, 1999, 28(4).

[9] Diana Laurillard. Applying educational research to design education[J]. Design Studies, 1982, 3(4).

[10] Tülay Akkoyun. Arts education and educating with arts[J]. Procedia - Social and Behavioral Sciences, 2009, 1(1) 